\title{
The Effect Of Simple Water Treatment Techniques And Methods Based On Local Resources Application For Post Flood, Mining, And Wet Land
}

\author{
Lenie Marlinae ${ }^{1}$, Danang Biyatmoko ${ }^{1}$, Husaini ${ }^{1}$, Chairul Irawan $^{1}$, Laily Khairiyati ${ }^{1}$, Agung Waskito ${ }^{1}$, Eko Suhartono ${ }^{1}$, \\ Syamsul Arifin', Andre Yusufa Febriandy ${ }^{1}$, Raudatul Jinan ${ }^{1}$
}

${ }^{\text {I}}$ Public Health Study Program, Faculty of Medicine, Lambung Mangkurat University, Banjarbaru, Indonesia

DOI: 10.29322/IJSRP.11.08.2021.p11647

http://dx.doi.org/10.29322/IJSRP.11.08.2021.p11647

\begin{abstract}
The existing water problem does not only originate from household waste, but also comes from floods, mining, and also wetland areas. At the time of a disaster, the availability of water is very crucial. The need for clean water for daily needs such as drinking, bathing, cooking, washing and so on is very difficult to fulfill in the midst of a flood disaster. In addition, mining involves a process that uses an open mining system involving a lot of heavy equipment for excavating the ground or using blasting. This results in the loss of the shape of the earth's surface resulting in a decrease in environmental quality. One of the impacts of the mining process is the emergence of Acid Mine Water (AAT). The formation of acid mine drainage is influenced by three main factors, namely water, air, and materials containing sulfide minerals. The dissolved pyrite compounds cause low water $\mathrm{pH}$ and also have high $\mathrm{Fe}$ and $\mathrm{Mn}$ metals. At the time of a disaster, the availability of water is very crucial. The need for clean water for daily needs such as drinking, bathing, cooking, washing and so on is very difficult to fulfill in the midst of a disaster such as a flood. Under normal conditions, the need for clean water is about 10 liters per person per day. The purpose of this study was to analyze the effect of simple water treatment techniques and methods based on local resources in providing clean water for post flood and mining.
\end{abstract}

Keywords: Water Treatment, Clean Water Sources, Post Floods, Mining, Wetland

\section{INTRODUCTION}

Water is one of the natural resources that has a very important function for human life and livelihood, as well as to promote public welfare so that it becomes the basic capital and main factor of development. Water is also an environmental component that is important for the survival of humans and other living things. This can be seen from the fact that $70 \%$ of This publication is licensed under Creative Commons Attribution CC BY. the earth's surface is covered with water and two thirds of the human body is made up of water. The first need for the implementation of good health is the availability of adequate water in terms of quantity and quality, which must meet the requirements of cleanliness and safety (Solihin, 2020).

The existing water problem does not only originate from household waste, but also comes from floods, mining, and also wetland areas. When a disaster occurs, the availability of water is very crucial. The need for clean water for daily needs such as drinking, bathing, cooking, washing and so on is very difficult to meet in the midst of a flood disaster. The reason is, the main problem of declining health is mostly due to an unsanitary environment due to lack of water and consuming polluted water (Dwiratna, 2018). In addition, mining involves a process that uses an open mining system involving a lot of heavy equipment for excavation or blasting. This results in the loss of shape of the earth's surface resulting in a decrease in environmental quality. One of the impacts of the mining process is the emergence of Acid Mine Water (AAT). The formation of acid mine drainage is influenced by three main factors, namely water, air, and materials containing sulfide minerals. Dissolved pyrite compounds cause low water $\mathrm{pH}$ and also have high $\mathrm{Fe}$ and $\mathrm{Mn}$ metals (Rahman, 2018).

When a disaster occurs, the availability of water is very crucial. The need for clean water for daily needs such as drinking, bathing, cooking, washing and so on is very difficult to meet in the midst of a disaster situation such as a flood. In normal conditions, the need for clean water is around 10 liters per person per day (Dwiratna, Pareira P and Kendarto, 2018)

South Kalimantan is one of the provinces in Indonesia which is a province that has a high risk of flooding in terms of its physical condition. The physical condition in South Kalimantan is mostly inundated during high rainfall. The water level when a flood occurs reaches 2-3 meters. Geographically, most of South Kalimantan is below sea level causing the water 
flow on the land surface to be less smooth. In addition to geographical factors, the cause of flooding is also due to rampant coal mining in the upstream and illegal logging (Angriani and Kumalawati, 2016).

Banjar Regency is one of 13 districts in South Kalimantan Province. Some areas of Banjar Regency are lowlands that are crossed by large rivers, such as the Martapura River, Riam Kanan River, Riam Kiwa River, as well as several small rivers whose hydrographic conditions are strongly influenced by rainfall. Banjar Regency has an average height of 84 meters above sea level (masl). The low location of Banjar Regency from above sea level causes the flow of water on the ground surface to be hampered. As a result, some areas are always inundated $(29.93 \%)$ while others $(0.58 \%)$ are periodically inundated. Based on these geographical conditions, Banjar Regency experiences flooding every year,

A report from BNPB South Kalimantan stated that there were 128 flood events in South Kalimantan during January 2021. The most widely received reports by BNPB South Kalimantan were from Banjar Regency as many as 38 reports. The average flood height in Banjar Regency is $89.4 \mathrm{~cm}$ (BNPB, 2021). BNPB data shows that throughout 2018-2020 South Kalimantan has experienced 73 floods that occurred in Balangan District, Banjar, Tanah Laut, Kotabaru, Tabalong, Tanah Bumbu, Tapin, Hulu Sungai Tengah, Banjarbaru City, Banjarmasin City, Hulu Sungai Selatan, and Upper North River. The impact of floods in South Kalimantan in 2021 on land cover is the largest in rice fields, which is around 36 hectares. In addition, as a result of the floods in South Kalimantan in early 2021, 5 people died, 27.

\section{MATERIALS AND METHODS}

Article searches were carried out using search engines using Google Scholar and Garuda Portal with keywords used were simple clean water treatment, water treatment in wetlands, mine water treatment, and flood water treatment. The total number of articles obtained was 1,889. After the articles were excluded because they did not meet the inclusion criteria, 20 articles were found that were suitable for review.

\section{FINDINGS \& DISCUSSION}

\section{Results of Analysis of Simple Water Treatment Methods and Techniques Based on Local Resources in Post-Flood Water Supply and Mining}

Based on the results of a study of several scientific articles that have been conducted, 13 articles were found with different simple water treatment methods and techniques.

In the research of Indra Wahyudin et al in 2018, the settling pond method in mining waste water management is an effective method in managing mine wastewater because from the monitoring period 2015 it is known that the percentage of This publication is licensed under Creative Commons Attribution CC BY. http://dx.doi.org/10.29322/IJSRP.11.08.2021.p11647 mine wastewater quality processed in WMP22 is categorized as good according to quality standards. with a $\mathrm{pH}$ value of 6.68 . While the good TSS value is $48.09 \mathrm{mg} / \mathrm{l}$. In accordance with the quality standards that have been set by the East Kalimantan Regional Regulation No. 2 of 2011.

Research by Muhammad Busyairi et al in 2018, one way to reduce acid mine water pollution is to carry out processing using coagulants and coagulation and flocculation processes. Coagulant is a chemical chemical potassium aluminum sulfate (KAl (SO4) 2. 12H2O). Several alternative materials can be developed as a substitute for coagulants. The assumption is that 1 gram of used aluminum can with $83.96 \%$ aluminum content produces 14.8990 grams of alum with the concentration used is $30 \%$ heating $70^{\circ} \mathrm{C}$ for 30 minutes and $8 \mathrm{M} \mathrm{H} 2 \mathrm{SO} 4$ concentration and $50^{\circ} \mathrm{C}$ drying. By utilizing the aluminum content of used beverage cans as a material for making alum ( $\mathrm{KAl}(\mathrm{SO} 4)$ 2. 12H2O) which is then used for processing acid mine drainage so that it can reduce levels of TSS, heavy metals $\mathrm{Fe}$ and $\mathrm{Mn}$ in acid mine drainage.

In the research of Sophia Dwiratna et al. In 2018, Coppola (2011) explained that treating dirty water through coagulation, flocculation and filtration processes will produce good water quality. Through this tool, the provision of clean water in flood conditions can be served. Household scale water treatment technology has the main objective of reducing pathogenic microorganisms, although there are several technologies that also reduce levels of chemical and radiological contamination. This technology is generally simple, easy to manufacture, and inexpensive considering that its target audience is the middle to lower class.

Siti Qomariyah et al in 2017, Retno Wimbaningrum et al in 2020, and Agus Panca Adi Sucahyo et al in 2018 said that constructed wetlands (CWs) with filter media of sand and gravel and aquatic plants were able to treat household waste with parameters TSS, pH , BOD, COD, Oils and Fats, and Detergents. Artificial wetlands are wastewater treatment systems that apply natural processes using shallow ponds or channels (less than $1 \mathrm{~m}$ ), aquatic plants, solid substrates (soil, sand and gravel) and microorganisms to improve wastewater quality. In addition, Wetland is also applied to manage extreme water $\mathrm{pH}$. Management of water pollution using wetlands using passive remediation technology. The wetland construction technology can separate dissolved metals such as $\mathrm{Fe}, \mathrm{Co}, \mathrm{Ni}, \mathrm{Mn}$ minerals.

Anita Megawati et al in 2014, safe drip is a water treatment method that is easy in distribution, able to meet the clean water needs of 6 families or 24 people according to the minimum standard of water needs in an emergency, namely 15 liters / person / day, able to provide clean water according to with chemical and physical parameters listed in the PERMENKES RI No. 492 of 2010 and has water quality that is almost the same as local water sources, has investment and 
operational costs that can be reached by a group of KK (Head of Families) whose clean water needs are served, although not all of the resources needed for the procurement and operation of Safe Drip are available. in local locations but these resources are still relatively easy to obtain,

Hardo Wahyudi et al in 2018, IPAL is one of the simplest methods of wastewater treatment that can be applied in the community because the tools and materials are easy to obtain. The equipment and materials used for the manufacture of tools and houses for the Communal IPAL include: hollow iron, welding wire, rubbing paper, faucets, buoys, pegs, paranets, small slap ropes, bamboo, plastic barrels, PVC pipes, pipe glue, connection pipes, pools, water pumps, solenoid valves, arduino, $\mathrm{pH}$ meters, TDS meters, relays, power supplies, panel boxes and cables.

Setyo Purwoto in 2011, a compact reactor in the form of 3 (three) column tubes with 7 treatments made it easier for the community when the electricity network went out and the availability of a pump was very difficult, so this series of tools has been set up not to use electricity, also without the need for a pump, but the product treated water remains optimal.

Didik Purwantoro et al in 2012, the materials for making clean water treatment techniques with a sand water filter are easy to obtain and the results of making this water filter can be used to provide and improve environmental hygiene and health, so that it is expected to improve the welfare of the community in the environment.

Nusa Idaman Said in 2014, active treatment systems generally require the addition of chemicals and routine maintenance. Active treatment can be designed to address any problem with acid mine drainage with various levels of acidity, flow rate and acidity load. Active treatment of acid mine drainage can be carried out using fixed equipment or portable equipment for in-situ treatment. Passive treatment systems are generally always used for post-closure acid mine water treatment scenarios, and are most suitable for acid mine waters with low acidity (<800 mg CaCO3 / L, small flow rates $(<50 \mathrm{~L} /$ sec) and acidity load due to it is low, namely $<100-150 \mathrm{~kg}$ $\mathrm{CaCO} 3$ / day.

Anshariah et al in 2015, dewatering is a method of removing water that has entered the sump pit by using a pump to the settling pond for processing. Water handling steps through dewatering are to analyze the maximum rainfall frequency, runoff discharge and pump capacity.

Firman Aziz Nugraha et al in 2020, according to Skousen and Jage (1998), the advantage of using organic materials in controlling acid mine drainage is to stimulate microbial growth and produce an anaerobic environment through sulfate reduction. Its other use of organic matter can reduce acidity by $20 \%$ (1500 to $1160 \mathrm{mg} / \mathrm{L}$ equivalent to $\mathrm{CaCO} 3$ ), and reduce $\mathrm{Fe}$, $\mathrm{Mn}$, and Al. Apart from that, organic waste can also be used to raise the $\mathrm{pH}$ of the water. The increase in water $\mathrm{pH}$ is due to the large number of negative functional groups in organic waste that bind $\mathrm{H}+$ ions causing acidic water.

Azwardi Imani et al in 2020, with the preparation of the activated carbon method using a container to accommodate bagasse, knives and cutting boards. The manufacture of activated carbon uses a porcelain cup (evaporating basin), oven, furnace, desiccator, iron grinder, 200 mesh sieve, and whattman 42 filter paper. The ingredients for making activated carbon are: bagasse, aquabides, $0.1 \mathrm{~N}$ HCL solution.

Marina et al in 2020, waste pepper skin that has been cleaned and then dried in the sun. After drying, the waste was pre-carbonized using an oven at $70^{\circ} \mathrm{C}$ for 3 hours. Furthermore, it is done grinding and sieving using a mesh. The next step is pepper peel waste carbon (KAKL) activated using $3 \mathrm{M} \mathrm{KOH}$ solution activator, then stirred using a stirrer until homogeneous and then allowed to stand for 24 hours. The soaked carbon was washed using distilled water until the $\mathrm{pH}$ was neutral and filtered using whattman filter paper No. 41 to form an activated carbon precursor. Activated carbon precursors are then physically activated in a furnace that flows with $\mathrm{N} 2$ gas at a temperature of $800^{\circ} \mathrm{C}$ with holding for 3 hours. Furthermore, the activated carbon is washed using distilled water to a neutral $\mathrm{pH}$. The morphology and composition of the activated carbon sample were known through characterization using the Scanning Electron Microscope-Energy Dispersive X-Ray Spectrometer (SEM-EDX) before testing as an absorbent material.

Firman Aziz Nugraha et al in 2020, in this study, the vertical flow system used is a downward vertical flow that utilizes gravity or downflow. In the vertical downhill type, water is flowed into the artificial wetland from the top layer of the media and an outlet channel is made at the bottom of the media, so that the water will flow downward by passing through the root zone by gravity. In this downward vertical flow system, it is expected that there will be direct contact between the root zone of the typha plant and the acid water of the coal mine. So that the process of reducing $\mathrm{Fe}$ and $\mathrm{Mn}$ can be achieved. In addition, microorganisms are also expected to play a role in this system.

\section{Results of Simple Water Treatment based on Local Resources in the Provision of Clean Water for Post Flood and Mining}

Research by Muhammad Busyairi et al in 2018 explained the coagulation-flocculation process with the addition of coagulant to form easily precipitated flocs. The reduction of metal elements occurs due to chemical precipitation in wastewater treatment with the addition of chemicals, the deposition of dissolved and suspended materials in water to form precipitates. This decrease in metallic elements is converted from ionic charge to particulate by the coagulant so that it can be precipitated. When coagulants are added to water or wastewater, colloid destabilization occurs and flocculant particles are 
formed. The addition of coagulant increases the $\mathrm{pH}$ value because the $\mathrm{OH}$ - ions will combine with $\mathrm{H}+$ ions, thereby decreasing the concentration of $\mathrm{H}+$ ions as a result, the $\mathrm{pH}$ value increases.

Hardo Wahyudi et al in 2018 explained that with the WWTP method in clean water treatment, waste water can be reused as an arena or area for education and recreation or relaxation.

Setyo Purwoto in 2011, the clean water treatment process in the reactor is carried out as follows; Water from floodwaters as raw water is filtered in (A), then flows through faucets (1) is contacted with PAC from (B) and flows downward, there is sedimentation in column (I). The water flow continues to rise and enter the Zeolite adsorbent (C). Then it flows up to the cation resin (E) to reduce the cations from the water. The resin contact is passed to the anion resin (D). After leaving the ion exchange, the chlorine solution infusion is injected through a funnel $(F)$. To remove odor, absorbance was performed at $(\mathrm{G})$ using CA. Then the series of water purification processes is complete. Flood water treatment with a compact reactor model in the form of 3 (three) tube columns with 7 treatments, namely: Filter, Poly Aluminum Chloride (PAC), Zeolite,

Anshariah et al. 2015, steps to handle water through dewatering, namely by analyzing the frequency of maximum rainfall, runoff discharge and pump capacity. The maximum rainfall frequency in the study area is $107.738 \mathrm{~mm}$, the amount of runoff that enters the sump is $0.85 \mathrm{~m} 3 / \mathrm{second}$ with a concentration time of 22.51 minutes. The capacity of the pump used to discharge water is $639 \mathrm{~m} 3 /$ hour with the ability to handle a total head of $56,689 \mathrm{~m}$ from an elevation of 0 to $41 \mathrm{~m}$. The processing is carried out at the settling pond using the active treatment method, namely the administration of $75 \mathrm{~kg}$ of alum and $50 \mathrm{~kg}$ of lime directly in a fast stirring pond with power supplied from a hydraulic plunge of $2,040.5 \mathrm{Nm} / \mathrm{sec}$ and a stirring gradient of $14,440.6$. Stirring is carried out so that the alum and lime are evenly distributed in the treatment water, which is expected to occur in a flocculation process so that it can accelerate the deposition of particles and stabilize the $\mathrm{pH}$. The results of the evaluation showed sediment stabilization in each existing pond compartment with a total detention time of 9,519 hours, it was concluded that it was safe for scouring by not exceeding the value of the requirements for the number $\operatorname{Re}<2,000$ and the Froude number 0.0005 .

Firman Aziz Nugraha et al in 2020, Dynamics of TSS values and iron and manganese metal content in the Anaerobic Wetland system, subsurface flow fluctuates with respect to the day with an increase in $\mathrm{Fe}$ concentration, and an increase in $\mathrm{pH}$ value. This is related to the components in the system, such as the characteristics of compost and oil bunches, microorganisms, plants and physical factors, such as sedimentation and filtration.

Agus Panca Adi Sucahyo et al in 2018 Catchnent the copper mineral research area in this study is $400 \mathrm{ha}$, the average runoff discharge is around $600 \mathrm{lt} / \mathrm{second}$, the dissolved metal content of the dissolved metal content is an average of $\mathrm{Cu} 5.38$ $\mathrm{mg} / \mathrm{l}, \mathrm{Fe} 4.57 \mathrm{mg} / 1$ and $\mathrm{pH} 4.1$ (mine hole discharge). The wetland design was applied in the research area using passive remediation.

Sri Sutyasmi et al in 2013, the results of the simulation results showed that the Biological Oxygen Demand (BOD), Chemical Oxygen Demand (COD) and Total Suspended Solids (TSS) were $191 \mathrm{mg} / \mathrm{l}$, respectively; $6.24 \mathrm{mg} / \mathrm{l}$; and $24 \mathrm{mg} / \mathrm{l}$ while after going through the wetland system $409 \mathrm{mg} / \mathrm{l}$ respectively; $10.32 \mathrm{mg} / \mathrm{l}$; and $145 \mathrm{mg} / \mathrm{l}$. The results of the water quality test results of the experiment meet the requirements in SNI 06-06491989 concerning Water for tanning leather.

Azwardi Imani et al in 2020, the results of the quality test for activated charcoal have met the standards required by the SNI regulation No. 06-3730-1995. The optimum weight of bagasse activated charcoal is 3 grams for 60 minutes. Iron content was obtained at $4 \mathrm{mg} / \mathrm{L}$ with a removal percentage of $79.65 \%$ and Manganese content was obtained at $4.12 \mathrm{mg} / \mathrm{L}$ with a removal percentage of $60.00 \%$ in acid mine drainage. Manganese content values still do not meet the quality standards set by the Minister of Environment Decree No. 113 of 2003.

Sri Aprilia et al in 2013, hSEM test results show that the membrane has a pore with an asymmetric structure. The ultrafiltration test that started with the coagulation process was able to detect $92.5 \%$ water color, with flux gain reaching 364.8 $\mathrm{ml} / \mathrm{m} 2 . s$.

Firman Aziz Nugraha et al in 2020, the Anaerobic Wetland system with oil palm bunches and compost media can increase the $\mathrm{pH}$ at 1 day residence with a range of 6.42 to 7.70 2.The dynamics of TSS values and iron and manganese metal content in the Anaerobic Wetland system, the subsurface flow fluctuates with the day in increasing $\mathrm{Fe}$ concentration, and increasing $\mathrm{pH}$ value. This is related to the components in the system, such as the characteristics of compost and oil bunches, microorganisms, plants, and physical factors, such as sedimentation and filtration. Thus, further research is needed to determine the correlation of the impact produced by each component on the remediation process.

Jacek Retka et al. In 2020, acid mine drainage (AMD) was characterized by low $\mathrm{pH}(\sim 3)$, high zinc concentration ( $750 \mathrm{mg} \cdot \mathrm{L}-1)$, and high sulfate content $(\sim 6800 \mathrm{mg} \cdot \mathrm{L}-1)$. On the other hand, the determinations made for flotation wastewater show, among other things, a $\mathrm{pH}$ of about 12 and ca. $780 \mathrm{mg} \mathrm{L} 1$ sulfate. AMD and neutralization of flotation wastewater by waste rock proved possible and efficient. However, in both cases, the final solution contains high concentrations of metals and sulfates. Premixing AMD with alkaline flotation wastewater in the first step and then neutralizing the obtained mixture with waste rock is considered the best solution. The resulting solution 
has a circumneutral $\mathrm{pH}$. However, the solutions obtained do not meet the legislative requirements but can be further addressed by, for example, passive treatment system. It is noteworthy that the proposed approach is low-cost and does not require any chemical reagents.

Muhammad Firman et al in 2018, the water that was cloudy after going through water treatment or filters changed its color to become clearer. Water that used to taste sour after going through a water treatment or filter has a fresher taste. Water that used to smell like rust because it contains iron after going through a water treatment or filter, the taste of iron in the water is greatly reduced.

\section{CONCLUSION}

Based on the 20 articles obtained, there are 2 articles $(10 \%)$ that use the settling pond method, 3 articles $(15 \%)$ that use the coagulation method, there are 6 articles $(30 \%)$ that use the wetland method (artificial wetland), 3 articles ( $25 \%$ ) using the filtration method, 1 article (5\%) using the safe drip method, 1 article (5\%) using the compact reactor model method, 1 article $(5 \%)$ using the acid and alkaline treatment system method, 1 article $(5 \%)$ using the solar power plant method, 1 article $(5 \%)$ using the method of adding calcium hydroxide solution, adding lime, increasing the cascade system and applying the baffle aerator, 3 articles (15\%) using the adsorption method. While the research proposal uses existing resources in the community in flood and mining areas. Examples include using gravel, silica sand, charcoal, palm fiber, clay, lime, alum, chlorine, and other additives. In addition, the research proposal also uses the mix method (quantitative and qualitative) method.

\section{REFERENCES}

Anshariah, Widodo S, Nuhung R. 2015. Studi Pengelolaan Air Asam Tambang pada PT. Rimau Energy Mining Kabupaten Barito Timur Provinsi Kalimantan Tengah. Jurnal Geomine, 1(1).

Busyairi M, Sarwono E, Priharyati A. 2018. Pemanfaatan Aluminium dari Limbah Kaleng Bekas Sebagai Bahan Baju Koagulan Untuk Pengolahan Air Asam Tambang. Jurnal Sains \& Teknologi Lingkungan, 10(1), 15-25.

Dwiratna S, Pareira BM, Kendarto DR. 2018. Pemberdayaan Masyarakat dalam Pengolahan Air Banjir Menjadi Air Baku di Daerah Rawan Banjir. Dharmakarya, 7(1), 75-79.

Megawati A. 2014. Analisis Kelayakan Safe Drip sebagai Teknologi Pengolahan Air pada Bencana Banjir. JURNAL SUMBER DAYA AIR, 10(1), 13-28.

Nugraha FA, Kirmi H, Haryanto B, dkk. 2020. Analisis Penggunaan Media Tandan Sawit dan Kompos dengan Sistem Aerobic Wetland dalam Mengolah Air Asam Tambang. SPECTA Journal of Technology, 4(2), 35-44.

Purwantoro D, Lutjito, Suparman. 2012. Pembuatan Pengolah Air Kotor Menjadi Air Bersih pada Daerah Banjir di Dusun Kalidengen II Temon Kulon Progo. INOTEKS, 16(2). This publication is licensed under Creative Commons Attribution CC BY. http://dx.doi.org/10.29322/IJSRP.11.08.2021.p11647
Purwoto S. 2011. Reaktor Pengolah Air Bersih Iptek bagi Masyarakat untuk Daerah Rawan Bencana. WAKTU: Jurnal Teknik UNIPA, 9(1), 1-7.

Qomariyah S, Koosdaryani, Muttaqien AY. 2017. Lahan Basah Buatan Sebagai Pengolah Limbah Cair dan Penyedia Air Non-Konsumsi. Jurnal Riset Rekayasa Sipil, 1(1), 25-32.

Said NI. 2014. Teknologi Pengolahan Air Asam Tambang Batubara "Alternatif Pemilihan Teknologi". Jurnal Air Indonesia, 7(2).

Sucahyo APA, Bargawa WS, Nurcholis M, dkk. 2018. Penerapan Wetland untuk Pengelolaan Air Asam Tambang. ournal Technology of Civil, Electrical, Mechanical, Geology, Mining and Urban Design, Kurvatek, doi, 10.

Wahyudi H, Jum'ati N, Khanif FA, dkk. 2018. Grey Water dan Air Banjir Layak Pakai Sebagai Upaya Pemenuhan Kebutuhan Air Bersih. Prosiding Konferensi Nasional Pengabdian Kepada Masyarakat dan Corporate Social Responsibility (PKM-CSR), 1, 375-385.

Wahyudin I, Widodo S, Nurwaskito A. 2018. Analisis Penanganan Air Asam Tambang Batubara. Jurnal Geomine. 6(2)

Wimbaningrum R, Arianti I, Sulistiyowati H. 2020. Efektivitas Tanaman Lembang (Typha angustifolia L.) di Lahan Basah Buatan dalam Penurunan Kadar TSS, BOD dan Fosfat pada Air Limbah Industri Laundry. BERKALA SAINSTEK, 8(1), 25-28. 